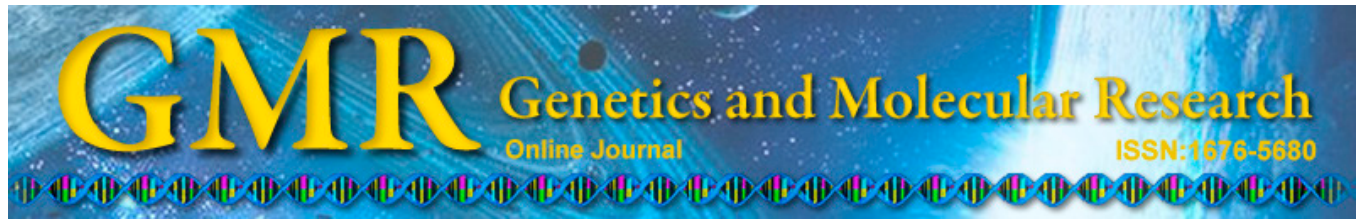

\title{
Identification of single nucleotide polymorphisms in the $A S B 15$ gene and their associations with chicken growth and carcass traits
}

\author{
Y.C. Wang ${ }^{1,2}$, R.R. Jiang ${ }^{2}$, X.T. Kang ${ }^{2,3}$, Z.J. Li ${ }^{2}$, R.L. Han ${ }^{2}$, J. Geng', \\ J.X. Fu' ${ }^{2}$, J.F. Wang ${ }^{1}$ and J.P. Wu ${ }^{1}$ \\ ${ }^{1}$ College of Animal Science and Technology, Gansu Agricultural University, \\ Lanzhou, China \\ ${ }^{2}$ College of Animal Husbandry and Veterinary Engineering, \\ Henan Agricultural University, Zhengzhou, China \\ ${ }^{3}$ Henan Research Center of Breeding Resources for Poultry, Zhengzhou, \\ China
}

Corresponding author: J.P. Wu

E-mail:wujp@gsau.edu.cn

Genet. Mol. Res. 14 (3): 11377-11388 (2015)

Received February 17, 2015

Accepted May 4, 2015

Published September 25, 2015

DOI http://dx.doi.org/10.4238/2015.September.25.5

\begin{abstract}
A S B 15$ is a member of the ankyrin repeat and suppressor of cytokine signaling box family, and is predominantly expressed in skeletal muscle. In the present study, an $\mathrm{F}_{2}$ resource population of Gushi chickens crossed with Anka broilers was used to investigate the genetic effects of the chicken ASB15 gene. Two single nucleotide polymorphisms (SNPs) (rs315759231 A $>\mathrm{G}$ and $\mathrm{rs} 312619270 \mathrm{~T}>\mathrm{C}$ ) were identified in exon 7 of the $A S B 15$ gene using forced polymerase
\end{abstract}


chain reaction-restriction fragment length polymorphism and DNA sequencing. One was a missense SNP (rs315759231 A>G) and the other was a synonymous SNP (rs312619270 T $>$ C). The rs315759231 A $>$ G polymorphism was significantly associated with body weight at birth, 12-week body slanting length, semi-evisceration weight, evisceration weight, leg muscle weight, and carcass weight $(\mathrm{P}<0.05)$. The rs312619270 $\mathrm{T}>\mathrm{C}$ polymorphism was significantly associated with body weight at birth, 4,8 , and 12 -week body weight, 8 -week shank length, 12-week breast bone length, 8 and 12-week body slanting length, breast muscle weight, and carcass weight $(\mathrm{P}<0.05)$. Our results suggest that the $A S B 15$ gene profoundly affects chicken growth and carcass traits.

Key words: Chicken; $A S B 15$ gene; Single nucleotide polymorphism; Growth and carcass traits

\section{INTRODUCTION}

The ankyrin repeat and suppressor of cytokine signaling (SOCS) box (ASB) family of proteins function as a substrate recognition subunit in a subset of Elongin-Cullin-SOCS (ECS) E3 ubiquitin ligases (Andresen et al., 2014). The different SOCS box-containing proteins have variable $\mathrm{N}$-terminal sequences that encode for domains that mediate protein-protein interactions and determine substrate recognition by ECS ligases (Kamura et al., 2004). Depending on the nature of such domains, ECSs can be divided into subfamilies, such as the SOCS, which exhibit an SH2 domain, and the larger $A S B$, which have 18 members that display ankyrin repeats at their $\mathrm{N}$ termini (Kile et al., 2001). $A S B$ family members function in multiple biological processes related to cell growth (Guibal et al., 2002), tissue development (Kohroki et al., 2001; Guibal et al., 2002), and insulin signaling (Wilcox et al., 2004).

$A S B 15$ is a member of the $A S B$ gene family, and is predominantly expressed in skeletal muscle (Hilton et al., 1998; Kile et al., 2000; McDaneld and Spurlock, 2008). ASB15 is rapidly downregulated in response to $\beta$-adrenergic receptor agonists (McDaneld et al., 2004; Spurlock et al., 2006). In $\mathrm{C}_{2} \mathrm{C}_{12}$ myoblasts, $A S B 15$ causes delayed differentiation and altered protein synthesis, and local overexpression of $A S B 15$ in skeletal muscle in vivo stimulates a significant increase in muscle fiber diameter (McDaneld et al., 2006). ASB 15 plays a role in early myoblast differentiation, and its effects may be mediated in part by the PI3K/Akt signal transduction pathway. As an $A S B$ family member, $A S B 15$ should function in skeletal muscle growth (McDaneld et al., 2006); however, no evidence of such a role has been found in chickens.

An important goal in the production of meat animals is to increase muscle growth. Therefore, the purpose of this study (based on the roles of the $A S B$ family as described above) was to examine whether associations exist between single nucleotide polymorphisms (SNPs) in the ASB 15 gene and growth and carcass traits in chickens, in order to identify a possible candidate gene that affects meat production in chickens. 


\section{MATERIAL AND METHODS}

\section{Resource population}

An $F_{2}$ resource population as previously described (Han et al., 2010) was used in this study. Gushi (G) chickens (24 hens and two roosters), which is a slow-growing Chinese breed, and Anka (A) broilers (12 hens and four roosters), which is a fast-growing broiler, were hybridized. The $\mathrm{F}_{2}$ population consisted of four crossed families (A-roosters mated with G-hens) and three reciprocal families (G-roosters mated with A-hens). To build the $F_{2}$ population, nine $F_{1}$ females were selected from each of seven families (six unrelated rooster families and one half-sib). In total, $63 \mathrm{~F}_{1}$ females were mated with seven $\mathrm{F}_{1}$ males from seven families. The resource population was established over two hatches that occurred at two-week intervals, and included 42 grandparents, $70 \mathrm{~F}_{1}$ parents, and $836 \mathrm{~F}_{2}$ chickens. All of the chickens were reared under the same conditions, with free access to food and water.

\section{Phenotypic measurements}

The growth traits analyzed were body weight (BW) and body size indices, including shank length (SL), breastbone length (BBL), and body slanting length (BSL). BW was recorded every 2 weeks, from birth to slaughter. SL, BBL, and BSL were measured every 4 weeks.

In total, $836 \mathrm{~F}_{2}$ chickens were slaughtered at the age of 84 days. The carcass traits measured were semi-eviscerated weight (SEW), eviscerated weight (EW), breast muscle weight (BMW), leg muscle weight (LMW), and carcass weight (CW). Blood samples were collected and separated by centrifugation at $3000 \mathrm{~g}$ for $15 \mathrm{~min}$ at $4^{\circ} \mathrm{C}$. Serum samples were frozen at $-80^{\circ} \mathrm{C}$ until use.

\section{DNA samples and DNA pool for sequencing}

Genomic DNA samples were extracted from the serum using the phenol-chloroform method. The same number of DNA samples from $100 \mathrm{~F}_{2}$ individuals was pooled and diluted to a working concentration of $50 \mathrm{ng} / \mu \mathrm{L}$. The pooled DNA was then sent to Taihe Gene Biotechnology Co. Ltd (Beijing) for sequencing, using eight pairs of primers designed according to the $A S B 15$ gene sequence (Table 1).

\section{Forced polymerase chain reaction-restriction fragment length polymorphism (PCR-RFLP)}

In order to amplify 172-bp and 182-bp fragments in exon 7, which contained an rs $315759231 \mathrm{~A}>\mathrm{G}$ mutation and an $\mathrm{rs} 312619270 \mathrm{~T}>\mathrm{C}$ mutation, two primer pairs were designed according to the sequencing results, and a previously reported gene sequence of the chicken ASB15 gene (NC_006088). Primer P1 (F1, 5'-GGCTATCTTGGATGATCACATTTCGA-3'; R1, 5'-GTTACCACCTCTCACTGCCAC-3') was designed to amplify the 172-bp fragment that contained rs315759231 A>G. Primer P2 (F2, 5'-GCTGAATCATGGATATAATGTGCAG-3'; R2, 5'-GGCTAACGGAAAGAAGAAAG-3') was designed to amplify the 182-bp fragment that contained rs312619270 T>C. To create AsuII (TT/CGAA) and PvuII (CAG/CTG) 
restriction sites for genotyping, a point mismatch was introduced into the forward primers of $\mathrm{P} 1$ and $\mathrm{P} 2$, respectively.

Following optimization, PCRs were performed in a total volume of $25 \mu \mathrm{L}$ using $50 \mathrm{ng}$ DNA, primers ( $1 \mu \mathrm{M}$ each), and $12 \mu \mathrm{L}$ Taq Master Mix (CWBIO, Beijing, China). The PCR profile was as follows: $5 \mathrm{~min}$ at $94^{\circ} \mathrm{C}$ (denaturation), 32 cycles at $94^{\circ} \mathrm{C}$ for $30 \mathrm{~s}, 60^{\circ} \mathrm{C}(\mathrm{P} 1)$ or $58^{\circ} \mathrm{C}(\mathrm{P} 2)$ for $30 \mathrm{~s}$, and $72^{\circ} \mathrm{C}$ for $30 \mathrm{~s}$, with a final extension at $72^{\circ} \mathrm{C}$ for $10 \mathrm{~min}$.

The PCR products were digested by restriction enzymes (AsuII for rs $315759231 \mathrm{~A}>\mathrm{G}$ and $P v u I$ I for $\mathrm{rs} 312619270 \mathrm{~T}>\mathrm{C}$ ) overnight at $37^{\circ} \mathrm{C}$. The digested products were separated by electrophoresis on $2.0 \%$ agarose gel that was stained with ethidium bromide. Different genotypes of these two SNPs were confirmed by sequencing.

\section{Statistical analysis}

All of the data were analyzed using the SPSS 22.0 software. A linear mixed model procedure was used to analyze the relationship between the two SNPs and the related economic traits of the $\mathrm{F}_{2}$ resource population. Both additive and dominance effects were also estimated for the traits identified as having significant SNP associations using the REG procedure, where the additive effect was estimated as 1, 0, and -1 for AA (CC), AG (TC), and GG (TT), respectively, and the dominance effect was estimated as 1 and -1 for the homozygote and heterozygote, respectively. The statistical model used was as follows:

$$
\mathrm{Y}_{i j k l m}=\mu+\mathrm{G}_{i}+\mathrm{S}_{j}+\mathrm{H}_{k}+\mathrm{f}_{l}+\mathrm{e} \quad \text { (Equation 1) }
$$

where $Y_{i j k l m}$ represents the measurement of a trait, $\mu$ is the overall population mean, $G_{i}$ is the fixed effect of genotype ( $\mathrm{i}=3), S_{j}$ is the fixed effect of $\operatorname{sex}(\mathrm{j}=2), H_{k}$ is the fixed effect of hatch $(\mathrm{k}=2), f_{l}$ is the random effect of family $(1=7)$, and $e_{i j k l m}$ is the random error. The least squares method was used to investigate the effects of genotypes of $A S B 15$ polymorphisms on the target traits. Significance was set at $\mathrm{P}<0.05$, and Bonferroni tests were conducted in order to control for multiple comparisons.

Population genetic indices, including heterozygosity $\left(H_{\mathrm{E}}\right)$, effective number of alleles $\left(N_{\mathrm{E}}\right)$, and the polymorphism information content (PIC) were calculated according to Nei's methods (Nei and Roychoudhury, 1974) in PopGene (version 1.3.1) (Yeh et al., 1999).

Tests for linkage disequilibrium (LD) were performed using the SHEsis software platform (http://analysis.bio-x.cn/SHEsisMain.htm). $D^{\prime}$ and $\mathrm{r}^{2}$ are the most commonly used measures of LD; $\mathrm{r}^{2}>0.33$ is indicative of strong linkage disequilibrium (Ardlie et al., 2002). If $\mathrm{r}^{2}$ $>0.33$, haplotypes were constructed on the basis of the two SNPs in all of the experimental animals, using the SHEsis program.

\section{RESULTS}

\section{SNP identification and genotyping}

The chicken $A S B 15$ gene is composed of nine exons, which code for a protein with 588 amino acids. Firstly, we cloned and sequenced a 9389-bp fragment, which included the entire coding region and the intron sequences of the ASB15 gene. Eight pairs of prim- 
ers were then designed to detect SNPs by DNA pool sequencing in the nine exons and introns (Table 1). Six SNPs in the introns and two SNPs in the seventh exon were identified (Figure 1). Finally, we selected the two SNPs in the seventh exon for the next step. The SNPs rs315759231 A $>$ G and rs312619270 T $>C$ were confirmed using the forced PCRRFLP method. The former was a missense mutation from Asn to Ser, and the latter was a synonymous mutation.

Table 1. Primer pair sequences and characteristics of the chicken ASB15 gene.

\begin{tabular}{|c|c|c|c|c|c|}
\hline Position & Name & Primer $\left(5^{\prime}-3^{\prime}\right)$ & Size (bp) & $\operatorname{Tm}\left({ }^{\circ} \mathrm{C}\right)$ & Notes \\
\hline $1-484$ & E1 & $\begin{array}{l}\text { F: ATGACGGATGAAAGCGAAG } \\
\text { R: TGAGTGATGCCAGGGAGGT }\end{array}$ & 484 & 58.0 & Exon1, intron1 \\
\hline $1432-2452$ & E2-3 & $\begin{array}{l}\text { F: ACTTTTGTTGTGGGGGCTG } \\
\text { R: GTAGTGAGGTGGGGGTCGG }\end{array}$ & 1021 & 62.0 & Exon2-3, intron2-3 \\
\hline 2194-3472 & E4 & $\begin{array}{l}\text { F: ACTCAGTCCAACCATTCACCC } \\
\text { R: TCCCAAAGAAATCATCCAAAA }\end{array}$ & 1279 & 60.0 & Exon4, intron4 \\
\hline $4793-5622$ & E5 & $\begin{array}{l}\text { F: TGTTTTTATTGTTGCTTTTCC } \\
\text { R: TATGTAGGTCCCTCCTTGATT }\end{array}$ & 829 & 57.5 & Exon5, intron5 \\
\hline $5544-6504$ & E6 & $\begin{array}{l}\text { F: TTCCTACACTTCCATAATCCA } \\
\text { R: AAGAAAATGACCATCACACAG }\end{array}$ & 961 & 59.0 & Intron5, exon6, intron6 \\
\hline $6428-7167$ & E7 & $\begin{array}{l}\text { F: GGTGCTTCTGTGTTAGGATTTT } \\
\text { R: GGCTAACGGAAAGAAGAAAGTG }\end{array}$ & 740 & 56.0 & Exon7 \\
\hline $7475-8010$ & E8 & $\begin{array}{l}\text { F: TCAAACCTGTCAAGAGGAAT } 536 \\
\text { R: CAGTGGCAACAGGTAAAGA }\end{array}$ & 57 & & Exon8, intron8 \\
\hline $8680-9389$ & E9 & $\begin{array}{l}\text { F: TTAGTGTTAGTGTCATGGGC } \\
\text { R: CTATTCTAAATGTATCTCTTTTCCA }\end{array}$ & 709 & 56.0 & Exon9, intron8 \\
\hline
\end{tabular}

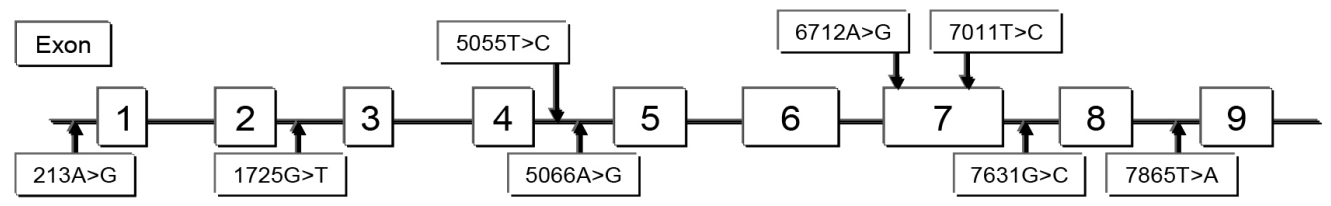

Figure 1. Single nucleotide polymorphism positions in the chicken ASB15 gene.

Three genotypes were detected from each of the two SNPs. The 172-bp PCR products that were digested into two fragments (146 and $26 \mathrm{bp}$ ) were marked AA, undigested (172 bp) fragments were marked GG, and those that were digested into three fragments $(172,146$, and $26 \mathrm{bp})$ were marked AG (Figure 2). The 182-bp PCR products were marked CC (157 and $25 \mathrm{bp})$, TT (182 bp), and CT (182, 157, and $25 \mathrm{bp}$ ) (Figure 3). Although the 26-bp and 25-bp fragments were too short to be visible on $2.0 \%$ agarose gel stained with ethidium bromide, three genotypes were confirmed by sequencing the corresponding PCR products (Figures 4 and 5). For the $\operatorname{rs} 315759231 \mathrm{~A}>\mathrm{G}$ site, the frequencies of alleles $\mathrm{A}$ and $\mathrm{G}$ were 0.491 and 0.509 , respectively. The genotype frequencies of $\mathrm{AA}, \mathrm{AG}$, and GG were $0.221,0.576$, and 0.203 , respectively (Table 2). The frequencies of alleles A and G were almost same, and the AA genotype frequency was approximately the same as the GG genotype frequency. For rs312619270 $\mathrm{T}>\mathrm{C}$, the allele frequencies of $\mathrm{T}$ and $\mathrm{C}$ were 0.747 and 0.253 , respectively, and the genotype frequencies of TT, TC, and CC were $0.581,0.332$, and 0.087 , respectively. Allele $\mathrm{T}$ was dominant in the $\mathrm{F}_{2}$ population, and the TT genotype was more frequent than the other genotypes. 


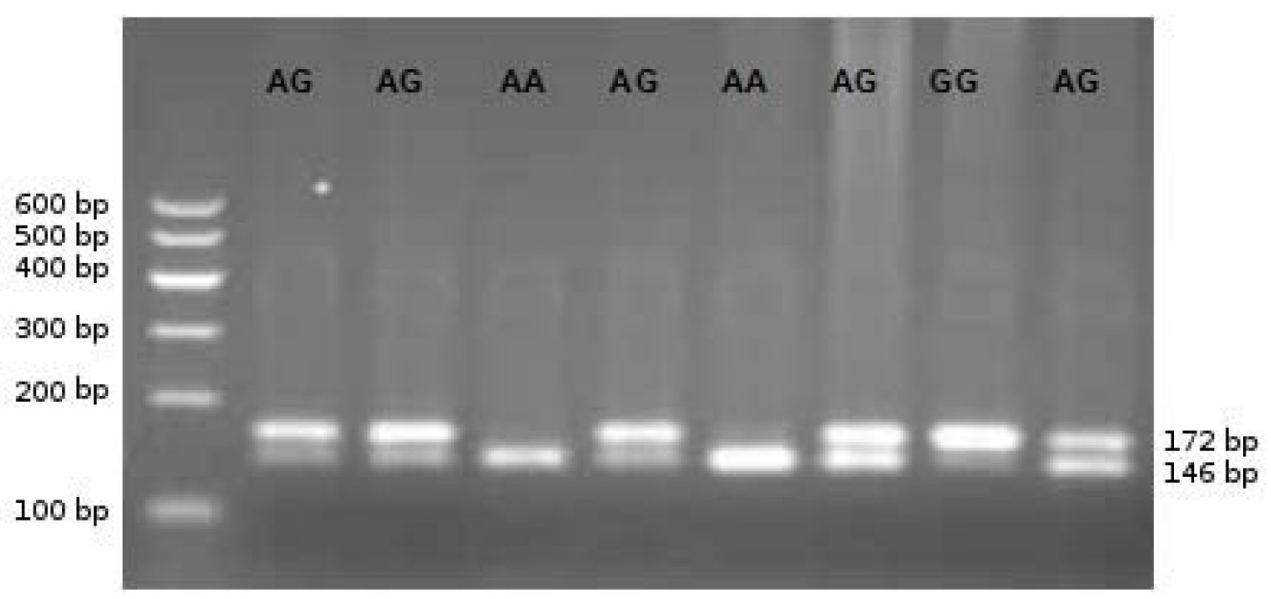

Figure 2. Agarose gel electrophoresis (2.0\%) showing $A s u$ II-restriction fragment length polymorphism fragments of the $A S B 15$ gene polymerase chain reaction amplification products.

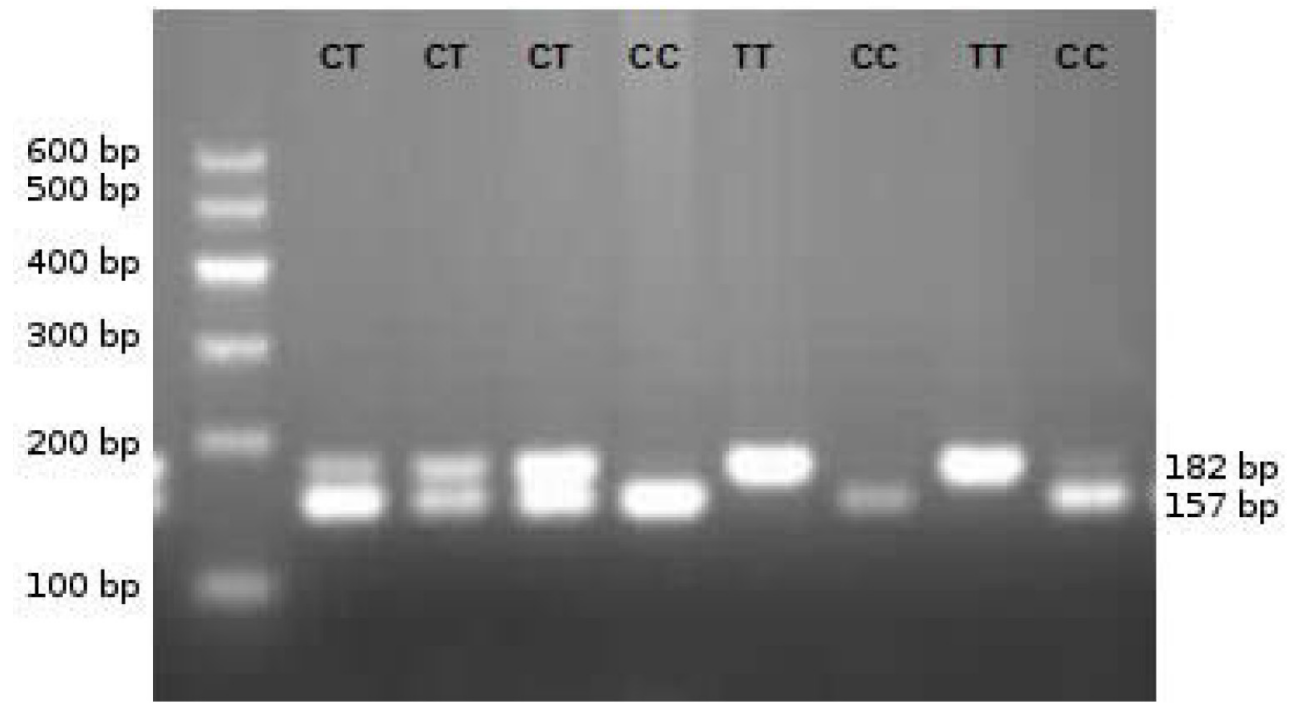

Figure 3. Agarose gel electrophoresis $(2.0 \%)$ showing the PvuII-restriction fragment length polymorphism fragments of the $A S B 15$ gene polymerase chain reaction amplification products.

Table 2. Genotypic and allelic frequencies (\%), and related genetic parameters.

\begin{tabular}{|c|c|c|c|c|c|c|c|c|}
\hline \multirow{2}{*}{$\begin{array}{l}\text { Locus } \\
\text { rs315759231 }\end{array}$} & \multicolumn{5}{|c|}{ Genotypic and allelic frequencies } & \multirow{3}{*}{$\begin{array}{c}H_{\mathrm{E}} \\
0.499\end{array}$} & \multirow{3}{*}{$\frac{N_{\mathrm{E}}}{1.999}$} & \multirow{3}{*}{$\begin{array}{c}\text { PIC } \\
0.375\end{array}$} \\
\hline & GG & AG & $\mathrm{AA}$ & A & $\mathrm{G}$ & & & \\
\hline \multirow{3}{*}{ rs312619270 } & 0.203 & 0.576 & 0.221 & 0.491 & 0.509 & & & \\
\hline & TT & CT & $\mathrm{CC}$ & $\mathrm{T}$ & $\mathrm{C}$ & & & \\
\hline & 0.581 & 0.332 & 0.087 & 0.747 & 0.253 & 0.378 & 1.608 & 0.307 \\
\hline
\end{tabular}

$H_{\mathrm{E}}=$ gene heterozygosity; $N_{\mathrm{E}}=$ number of allele; PIC = polymorphism information content. 


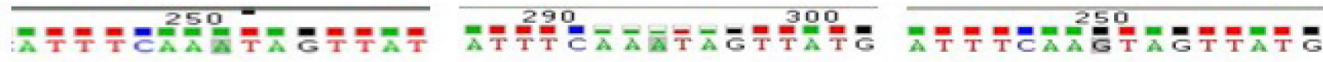

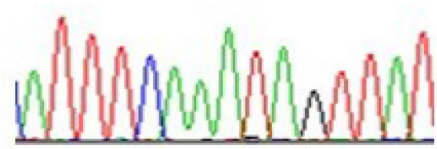

AA genotype

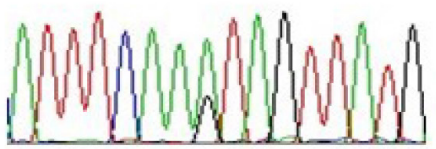

AG genotype

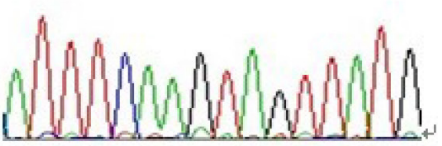

GG genotype

Figure 4. DNA sequencing files of AA, AG, and GG genotypes.

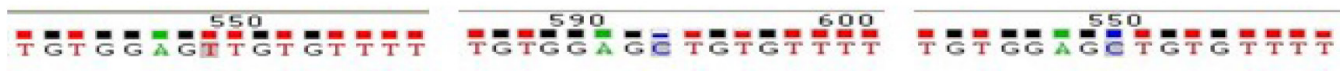

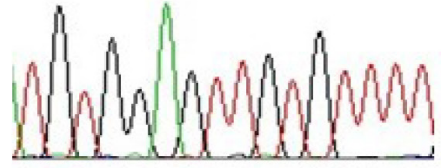

TT genotype

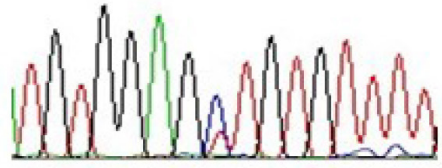

CT genotype

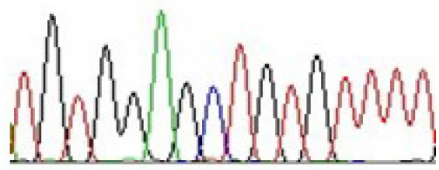

CC genotype

Figure 5. DNA sequencing files of TT, CT, and CC genotypes.

\section{Diversity analysis and linkage disequilibrium}

The genetic characteristics $\left(H_{\mathrm{E}}, N_{\mathrm{E}}\right.$, and PIC) of the $\mathrm{F}_{2}$ population are presented in Table 2. The value of $H_{\mathrm{E}}$ was approximately 0.5 for rs315759231 and rs312619270, and the $N_{\mathrm{E}}$ approached 2; the PIC values were 0.375 and 0.306 , respectively. PIC values greater than 0.50 were indicative of high levels of polymorphism, between 0.50 and 0.25 of intermediate levels of polymorphism, and lower than 0.25 of low levels of polymorphism. The $\mathrm{F}_{2}$ population exhibited intermediate levels of genetic diversity at these two SNPs. These results reflect a low overall level of genetic diversity of the chicken gene in the analyzed population. Genetic diversity is essential for species conservation, and the potential improvement of production traits in selected breeds.

The values of $D^{\prime}$ and $\mathrm{r}^{2}$ of the two SNPs were 0.115 and 0.004 , respectively; as $\mathrm{r}^{2}<$ 0.33 , the SNPs were not in linkage disequilibrium.

\section{SNP associations with growth and carcass traits}

A total of 17 growth traits and five carcass traits were used in an analysis of association. Regarding the growth traits, the rs $315759231 \mathrm{~A}>\mathrm{G}$ polymorphism was only significantly associated with BW0 and BSL12 (Table 3). A significant dominant effect on BW0 was found, while the additive effect was significant on BSL12 (Table 5). The rs312619270 T $>$ C polymor- 
phism was significantly associated with BW0, 4, 8, 12, and SL8, BBL12, BSL8, and BSL12 (Table 4); the CT individuals had significantly higher values of these traits than those with CC and TT genotypes.

\begin{tabular}{|c|c|c|c|c|c|}
\hline \multirow[t]{2}{*}{ Trait } & & \multicolumn{3}{|c|}{ Genotype } & \multirow[t]{2}{*}{$P$ value } \\
\hline & & GG (149) & AG (422) & AA (162) & \\
\hline \multirow[t]{17}{*}{ Growth traits } & BW0 (g) & $30.925 \pm 0.454^{b}$ & $30.304 \pm 0.419^{a b}$ & $31.240 \pm 0.449^{a}$ & 0.000 \\
\hline & BW2 (g) & $120.765 \pm 2.812$ & $122.525 \pm 2.522$ & $122.965 \pm 2.787$ & 0.515 \\
\hline & BW4 (g) & $317.135 \pm 7.913$ & $321.102 \pm 7.323$ & $325.386 \pm 7.846$ & 0.247 \\
\hline & BW6 (g) & $558.694 \pm 14.736$ & $559.896 \pm 13.579$ & $571.554 \pm 14.599$ & 0.278 \\
\hline & BW8 (g) & $804.623 \pm 20.589$ & $812.688 \pm 18.739$ & $835.888 \pm 20.354$ & 0.062 \\
\hline & $\mathrm{BW} 10(\mathrm{~g})$ & $1100.295 \pm 26.620$ & $1110.925 \pm 24.474$ & $1131.061 \pm 26.423$ & 0.196 \\
\hline & BW12 (g) & $1335.878 \pm 30.202$ & $1350.352 \pm 27.357$ & $1383.184 \pm 29.896$ & 0.067 \\
\hline & SLO $(\mathrm{cm})$ & $2.578 \pm 0.012$ & $2.574 \pm 0.009$ & $2.593 \pm 0.011$ & 0.127 \\
\hline & $\mathrm{SL} 4(\mathrm{~cm})$ & $5.469 \pm 0.075$ & $5.497 \pm 0.054$ & $5.543 \pm 0.073$ & 0.685 \\
\hline & SL8 $(\mathrm{cm})$ & $7.876 \pm 0.061$ & $7.912 \pm 0.038$ & $7.988 \pm 0.059$ & 0.372 \\
\hline & SL12 (cm) & $9.345 \pm 0.082$ & $9.395 \pm 0.067$ & $9.455 \pm 0.081$ & 0.373 \\
\hline & BBL4 $(\mathrm{cm})$ & $6.181 \pm 0.065$ & $6.210 \pm 0.055$ & $6.248 \pm 0.064$ & 0.505 \\
\hline & BBL8 (cm) & $8.905 \pm 0.081$ & $8.880 \pm 0.066$ & $8.985 \pm 0.079$ & 0.281 \\
\hline & $\operatorname{BBL} 12(\mathrm{~cm})$ & $10.937 \pm 0.049$ & $10.996 \pm 0.080$ & $11.004 \pm 0.092$ & 0.652 \\
\hline & BSL4 $(\mathrm{cm})$ & $11.311 \pm 0.099$ & $11.385 \pm 0.083$ & $11.488 \pm 0.098$ & 0.138 \\
\hline & BSL8 (cm) & $16.132 \pm 0.108$ & $16.257 \pm 0.077$ & $16.295 \pm 0.105$ & 0.400 \\
\hline & BSL12 (cm) & $19.643 \pm 0.117^{b}$ & $19.776 \pm 0.089^{\mathrm{ab}}$ & $19.955 \pm 0.114^{a}$ & 0.046 \\
\hline \multirow[t]{5}{*}{ Carcass traits } & SEW (g) & $1086.655 \pm 26.317^{b}$ & $1098.473 \pm 24.017^{\mathrm{ab}}$ & $1128.924 \pm 25.991^{a}$ & 0.041 \\
\hline & EW (g) & $903.108 \pm 23.999^{b}$ & $919.915 \pm 22.176^{\mathrm{ab}}$ & $943.985 \pm 23.740^{\mathrm{a}}$ & 0.024 \\
\hline & $\mathrm{BMW}(\mathrm{g})$ & $68.507 \pm 2.585$ & $70.238 \pm 2.386$ & $71.956 \pm 2.555$ & 0.110 \\
\hline & LMW (g) & $97.158 \pm 3.014^{b}$ & $99.308 \pm 2.785^{\mathrm{ab}}$ & $101.826 \pm 2.986^{\mathrm{a}}$ & 0.049 \\
\hline & CW (g) & $1195.165 \pm 29.04^{b}$ & $1211.406 \pm 26.722^{\mathrm{ab}}$ & $1247.964 \pm 28.747^{a}$ & 0.031 \\
\hline
\end{tabular}

${ }_{a, b}$ Means within a row of each SNP site with no common superscript were significantly different $(\mathrm{P}<0.05)$; bold numbers indicate significant differences. BW0, BW2, BW4, BW6, BW8, BW10, and BW12 represent body weight at $0,4,8$, and 12 weeks of age; SL4, SL8, and SL12 represent shank length at 4, 8, and 12 weeks of age; BBL4, BBL8, and BBL12 represent breast bone length at 4, 8, and 12 weeks of age; BSL4, BSL8, and BSL12 represent body slanting length at 4, 8, and 12 weeks of age; SEW, semi-evisceration weight; EW, evisceration weight; BMW, breast muscle weight; LMW, leg muscle weight; CW, carcass weight.

Regarding the carcass traits, the rs $315759231 \mathrm{~A}>\mathrm{G}$ polymorphism was significantly associated with SEW, EW, LMW, and CW. The values of these traits in the AA genotype were significantly higher than those in the GG and AG genotypes (Table 3). Values of SEW, $\mathrm{EW}, \mathrm{LMW}$, and CW were higher in the AA genotype than in the GG and AG genotypes. The rs312619270 T $>$ C polymorphism was only significantly associated with BMW and CW; trait values in the CT genotype were higher than those in the TT and CC genotypes. Both the dominant and additive effects were significant for weight (except BW0), SL8, BBL12, BSL8, BSL12, and BMW (Table 6).

\section{DISCUSSION}

Tremendous progress has been achieved in the fields of genetics and genomics over the last two decades (Gheyas and Burt, 2013). SNPs are by far the most commonly used tools for detecting DNA sequence variations. Although the vast majority of SNPs are found in noncoding regions of the genome, and most that are found in coding regions do not change gene products in deleterious ways, they are thought to be the basis for much of the genetic variation found in 
humans and animals (Kwok, 2003). The function of SNPs is a hot topic of debate for geneticists (Rao and Zhang, 2007). Among farm animals, the chicken has emerged as an important model organism, in fields as diverse as embryological development, immunology, oncology, virology, evolution, genetics, and genomics, and particularly as a model for other avian species. Studies of chicken SNPs have mainly focused on important economic characteristics, such as growth (Amills et al., 2003; Wang et al., 2011; Liu et al., 2012; Xie et al., 2012; Ahsan et al., 2013; Jin et al., 2013), carcass characteristics (Fang et al., 2010; Uemoto et al., 2011; Lu et al., 2012; Boschiero et al., 2013; Sun et al., 2013), egg quality (Bennett et al., 2006; Fatemi et al., 2012), fatness (Nie et al., 2010; Han et al., 2012), reproduction (Tang et al., 2010; Moonen and Villamor, 2011; Liu et al., 2012), and disease resistance (Legarra et al., 2011; Meydan et al., 2011).

\begin{tabular}{|c|c|c|c|c|c|c|}
\hline \multirow[t]{2}{*}{ SNP } & \multirow[t]{2}{*}{ Trait } & & \multicolumn{3}{|c|}{ Genotype } & \multirow[t]{2}{*}{$P$ value } \\
\hline & & & TT (441) & CT (252) & CC (66) & \\
\hline s312619270 & Growth traits & BW0 (g) & $30.560 \pm 0.566^{\mathrm{ab}}$ & $30.942 \pm 0.486^{a}$ & $29.983 \pm 0.47^{\mathrm{b}}$ & 0.027 \\
\hline \multirow{21}{*}{$\Gamma>C$} & & BW2 (g) & $121.475 \pm 2.432$ & $124.301 \pm 2.570$ & $121.229 \pm 3.280$ & 0.169 \\
\hline & & BW4 (g) & $317.188 \pm 6.336^{b}$ & $327.011 \pm 6.68^{a}$ & $325.779 \pm 8.187^{a b}$ & 0.033 \\
\hline & & BW6 (g) & $556.124 \pm 12.300$ & $568.690 \pm 12.956$ & $565.124 \pm 15.874$ & 0.229 \\
\hline & & BW8 (g) & $804.461 \pm 16.014^{b}$ & $832.264 \pm 17.043^{a}$ & $820.168 \pm 22.182^{\mathrm{ab}}$ & 0.042 \\
\hline & & BW10 (g) & $1100.614 \pm 20.902$ & $1131.654 \pm 22.209$ & $1114.304 \pm 28.241$ & 0.086 \\
\hline & & BW12 (g) & $1338.955 \pm 23.176^{b}$ & $1379.751 \pm 24.845^{a}$ & $1351.119 \pm 32.806^{\mathrm{ab}}$ & 0.048 \\
\hline & & SL0 $(\mathrm{cm})$ & $2.576 \pm 0.011$ & $2.584 \pm 0.012$ & $2.598 \pm 0.016$ & 0.211 \\
\hline & & $\mathrm{SL} 4(\mathrm{~cm})$ & $5.497 \pm 0.063$ & $5.494 \pm 0.071$ & $5.407 \pm 0.105$ & 0.643 \\
\hline & & SL8 $(\mathrm{cm})$ & $7.852 \pm \mathbf{0 . 0 4 3}^{\mathrm{b}}$ & $8.002 \pm 0.051^{\mathrm{a}}$ & $7.981 \pm \mathbf{0 . 0 8 8}^{\mathrm{ab}}$ & 0.016 \\
\hline & & $\mathrm{SL} 12(\mathrm{~cm})$ & $9.355 \pm 0.053$ & $9.468 \pm 0.060$ & $9.435 \pm 0.092$ & 0.091 \\
\hline & & BBL4 $(\mathrm{cm})$ & $6.193 \pm 0.053$ & $6.249 \pm 0.058$ & $6.257 \pm 0.080$ & 0.375 \\
\hline & & BBL8 $(\mathrm{cm})$ & $8.896 \pm 0.064$ & $8.948 \pm 0.071$ & $8.868 \pm 0.104$ & 0.570 \\
\hline & & $\operatorname{BBL} 12(\mathrm{~cm})$ & $10.918 \pm 0.064^{b}$ & $11.128 \pm 0.105^{a}$ & $11.080 \pm 0.072^{\mathrm{ab}}$ & 0.008 \\
\hline & & BSL4 $(\mathrm{cm})$ & $11.325 \pm 0.083$ & $11.550 \pm 0.124$ & $11.490 \pm 0.091$ & 0.057 \\
\hline & & BSL8 (cm) & $16.123 \pm 0.061^{b}$ & $16.403 \pm 0.077^{\mathrm{a}}$ & $16.385 \pm 0.144^{\mathrm{ab}}$ & 0.006 \\
\hline & & BSL12 $(\mathrm{cm})$ & $19.707 \pm 0.067^{b}$ & $19.908 \pm 0.081^{a}$ & $19.821 \pm 0.14^{\mathrm{ab}}$ & 0.048 \\
\hline & Carcass traits & $\mathrm{SEW}(\mathrm{g})$ & $1090.872 \pm 20.696$ & $1122.278 \pm 22.016$ & $1097.838 \pm 28.316$ & 0.076 \\
\hline & & $\mathrm{EW}(\mathrm{g})$ & $911.268 \pm 19.188$ & $939.342 \pm 20.266$ & $918.281 \pm 25.384$ & 0.063 \\
\hline & & BMW (g) & $69.114 \pm 2.076^{b}$ & $72.688 \pm 2.184^{\mathrm{a}}$ & $69.700 \pm 2.733^{\mathrm{ab}}$ & 0.018 \\
\hline & & LMW (g) & $98.669 \pm 2.584$ & $100.972 \pm 2.704$ & $99.233 \pm 3.313$ & 0.299 \\
\hline & & $\mathrm{CW}(\mathrm{g})$ & $1199.710 \pm 22.337^{b}$ & $1242.634 \pm 23.713^{a}$ & $1213.363 \pm 30.354^{\mathrm{ab}}$ & 0.015 \\
\hline
\end{tabular}

${ }^{a, b}$ Means within a row of each SNP site with no common superscript were significantly different $(\mathrm{P}<0.05)$; bold numbers indicate significant differences. BW0, BW2, BW4, BW6, BW8, BW10, and BW12 represent body weight at $0,4,8$, and 12 weeks of age; SL4, SL8, and SL12 represent shank length at 4, 8, and 12 weeks of age; BBL4, BBL8, and BBL12 represent breast bone length at 4, 8, and 12 weeks of age; BSL4, BSL8, and BSL12 represent body slanting length at 4, 8, and 12 weeks of age; SEW, semi-evisceration weight; EW, evisceration weight; BMW, breast muscle weight; LMW, leg muscle weight; CW, carcass weight.

Table 5. Estimated additive and dominance effects for the rs $315759231 \mathrm{~A}>\mathrm{G}$.

\begin{tabular}{lccccc}
\hline Traits & \multicolumn{2}{c}{ Additive effective } & & \multicolumn{2}{c}{ Dominance effective } \\
\cline { 2 - 3 } \cline { 5 - 6 } & $\mathrm{a} \pm \mathrm{SE}$ & P value & & $\mathrm{d} \pm \mathrm{SE}$ & $0.401 \pm 0.098$ \\
BW0 & $0.237 \pm 0.150$ & 0.114 & & $0.010 \pm 0.042$ & 0.000 \\
BSL12 & $0.124 \pm 0.063$ & 0.047 & & $0.000 \pm 0.075$ & 0.993 \\
SEW & $14.790 \pm 9.024$ & 0.102 & & $-0.117 \pm 0.074$ & 0.113 \\
EW & $14.726 \pm 7.762$ & 0.058 & & $-0.606 \pm 0.643$ & 0.346 \\
LMW & $1.665 \pm 0.969$ & 0.086 & & $-4.201 \pm 6.409$ & 0.512 \\
CW & $0.223 \pm 0.112$ & 0.048 & &
\end{tabular}

Genetics and Molecular Research 14 (3): 11377-11388 (2015) 


\begin{tabular}{|c|c|c|c|c|}
\hline \multirow[t]{2}{*}{ Traits } & \multicolumn{2}{|c|}{ Additive effective } & \multicolumn{2}{|c|}{ Dominance effective } \\
\hline & $\mathrm{a} \pm \mathrm{SE}$ & P value & $\mathrm{d} \pm \mathrm{SE}$ & $P$ value \\
\hline BW0 & $0.296 \pm 0.160$ & 0.640 & $0.020 \pm 0.106$ & 0.851 \\
\hline BW4 & $5.983 \pm 2.629$ & 0.023 & $-5.681 \pm 1.753$ & 0.001 \\
\hline BW8 & $16.347 \pm 7.582$ & 0.031 & $-18.806 \pm 4.984$ & 0.000 \\
\hline BW12 & $24.062 \pm 11.497$ & 0.037 & $-33.814 \pm 7.477$ & 0.000 \\
\hline SL8 & $0.082 \pm 0.038$ & 0.033 & $-0.063 \pm 0.025$ & 0.013 \\
\hline BBL12 & $0.153 \pm 0.040$ & 0.000 & $-0.088 \pm 0.026$ & 0.001 \\
\hline BSL8 & $0.142 \pm 0.066$ & 0.030 & $-0.098 \pm 0.043$ & 0.023 \\
\hline BSL12 & $0.146 \pm 0.062$ & 0.019 & $-0.093 \pm 0.041$ & 0.023 \\
\hline BMW & $2.253 \pm 0.889$ & 0.011 & $-3.140 \pm 0.575$ & 0.000 \\
\hline $\mathrm{CW}$ & $23.104 \pm 10.267$ & 0.025 & $-0.065 \pm 0.078$ & 0.408 \\
\hline
\end{tabular}

In this study, two SNPs were found in the chicken $A S B 15$ gene in exon 7. One was a missense SNP (rs315759231 A>G) and the other was a synonymous SNP (rs312619270 $\mathrm{T}>\mathrm{C}$ ). They were detected and genotyped by DNA pool sequencing and the forced PCR-RFLP method. Polymerase chain reaction-single-strand conformation polymorphism (PCR-SSCP), PCR-RFLP, and direct DNA sequencing are three popular methods for the detection of DNA mutations. DNA pool sequencing and forced PCR-RFLP were used in this study in preference to the numerous steps of the SSCP method, its inaccuracies, complicated technical demands, slow speed, and poor reproducibility. Interestingly, in this study the forced PCR-RFLP method was able to accurately detect polymorphisms in the chicken ASB15 gene, and the positions of the mutations were found by DNA pool sequencing; the birds were genotyped using forced PCR-RFLP.

In view of the function of $A S B 15$ in growth and carcass traits, we firstly studied its SNPs. Our results revealed that two SNPs (rs315759231 A $>$ G and rs312619270 T $>C$ ) of the ASB15 gene are located in exon 7 and belong to different mutations. The rs315759231 A>G polymorphism results in an amino acid change, from Asn to Ser. This missense SNP polymorphism was mainly associated with traits related to carcass traits, including SEW, EW, LMW, and CW. Therefore, rs315759231 A $>$ G may affect chicken carcass traits, particularly of the leg muscle. Its AA genotype had significantly higher trait values than the GG and AG genotypes. McDaneld and Spurlock (2008) reported that $A S B 15$ is an $A S B$ gene family member that is predominantly expressed in skeletal muscle. $A S B 15$ participates in the regulation of protein turnover and muscle cell development, by stimulating protein synthesis and regulating the differentiation of muscle cells. The synonymous SNP ( $r 312619270 \mathrm{~T}>\mathrm{C}$ ) was associated with traits related to growth and carcass traits, including BW4, 8, 12, SL8, BBL12, BSL8, BSL12, BMW, and CW. These traits have significant additive effects, which would inhibit their use in breeding. Therefore, rs312619270 T $>$ C may affect chicken growth. The trait values of the CT genotype were higher than those of the TT and CC genotypes. Dong et al. (2013) reported that $A S B 15$ is only expressed in heart and skeletal muscle, and has different expression levels in skeletal muscle at different stages. The expression level of $A S B 15$ is increasing with its growth at different stages (Dong et al., 2013).

Polymorphisms in the ASB15 gene probably affect transcription factor binding and mRNA expression levels. These associations can be explained as follows: firstly, the missense mutation (rs315759231 A $>$ G) could affect mRNA expression; secondly, the synonymous SNP (rs312619270 T $>$ C) is a silent mutation; however, some synonymous changes can affect splicing, mRNA stability, or translational efficiency (Chamary et al., 2006). 
In conclusion, the SNPs rs315759231 $\mathrm{A}>\mathrm{G}$ and $\mathrm{rs} 312619270 \mathrm{~T}>\mathrm{C}$ were identified in the seventh exon of the chicken $A S B 15$ gene. The rs315759231 polymorphism was significantly related to SEW, EW, LMW, and CW, and the rs312619270 polymorphism was significantly related to BW and body measurements. Therefore, the $A S B 15$ gene probably has a profound effect on growth and carcass traits in the chicken. These SNPs can assist researchers in selecting optimal strains and phenotypes for further experiments, because growth and carcass traits are important characteristics in the poultry industry. Our analyses also provide a basis for the further functional annotation of ASB15. ASB15 may be a good candidate gene to improve growth and carcass traits in the chicken, but further research is required to confirm this.

\section{Conflicts of interest}

The authors declare no conflict of interest.

\section{ACKNOWLEDGMENTS}

Research supported by the Agricultural Research Outstanding Talents and Innovation Team of the Ministry of Agriculture of China and Earmarked Fund for Modern Agro-Industry Technology Research System (\#CARS-41-K04) and Program for Innovation Research Team of Ministry of Education (\#IRT1236).

\section{REFERENCES}

Ahsan M, Li X, Lundberg AE, Kierczak M, et al. (2013). Identification of candidate genes and mutations in QTL regions for chicken growth using bioinformatic analysis of NGS and SNP-chip data. Front. Genet. 4: 226.

Amills M, Jimenez N, Villalba D, Tor M, et al. (2003). Identification of three single nucleotide polymorphisms in the chicken insulin-like growth factor 1 and 2 genes and their associations with growth and feeding traits. Poultr. Sci. 82: 1485-1493.

Andresen CA, Smedegaard S, Sylvestersen KB, Svensson C, et al. (2014). Protein interaction screening for the ankyrin repeats and suppressor of cytokine signaling (SOCS) box (ASB) family identify Asb11 as a novel endoplasmic reticulum resident ubiquitin ligase. J. Biol. Chem. 289: 2043-2054.

Ardlie K G, Lunetta KL, and Seielstad M (2002). Testing for population subdivision and association in four case-control studies. Am. J. Hum. Genet. 71: 304-311.

Bennett AK, Hester PY and Spurlock DE (2006). Polymorphisms in vitamin D receptor, osteopontin, insulin-like growth factor 1 and insulin, and their associations with bone, egg and growth traits in a layer-broiler cross in chickens. Anim. Genet. 37: 283-286.

Boschiero C, Jorge EC, Ninov K, Nones K, et al. (2013). Association of IGF1 and KDM5A polymorphisms with performance, fatness and carcass traits in chickens. J. Appl. Genet. 54: 103-112.

Chamary JV, Parmley JL and Hurst LD (2006). Hearing silence: non-neutral evolution at synonymous sites in mammals. Nat. Rev. Genet. 7: 98-108.

Dong X, Zhong T, Xu T, Xia Y, et al. (2013). Evaluating coverage of exons by HapMap SNPs. Genomics 101: 20-23.

Fang M, Nie Q, Luo C, Zhang D, et al. (2010). Associations of GHSR gene polymorphisms with chicken growth and carcass traits. Mol. Biol. Rep. 37: 423-428.

Fatemi SA, Mehrabani-Yeganeh H, Nejati-Javaremi A and Niknafs Sh (2012). Association of neuropeptide Y and gonadotropin-releasing hormone receptor gene SNPs with breeding value for growth and egg production traits in Mazandaran native chickens. Genet. Mol. Res. 11: 2539-2547.

Gheyas AA and Burt DW (2013). Microarray resources for genetic and genomic studies in chicken: a review. Genesis 51: 337-356.

Guibal FC, Moog-Lutz C, Smolewski P, Di Gioia Y, et al. (2002). ASB-2 inhibits growth and promotes commitment in myeloid leukemia cells. J. Biol. Chem. 277: 218-224.

Han R, Wei Y, Kang X, Chen H, et al. (2012). Novel SNPs in the PRDM16 gene and their associations with performance traits in chickens. Mol. Biol. Rep. 39: 3153-3160. 
Han RL, Lan XY, Zhang LZ, Ren G, et al. (2010). A novel single-nucleotide polymorphism of the visfatin gene and its associations with performance traits in the chicken. J. Appl. Genet. 51: 59-65.

Hilton DJ, Richardson RT, Alexander WS, Viney EM, et al. (1998). Twenty proteins containing a C-terminal SOCS box form five structural classes. Proc. Natl. Acad. Sci. 95: 114-119.

Jin S, Chen S, Li H, Lu Y, et al. (2013). Polymorphisms in the transforming growth factor Beta3 gene and their associations with feed efficiency in chickens. Poultr. Sci. 92: 1745-1749.

Kamura T, Maenaka K, Kotoshiba S, Matsumoto M, et al. (2004). VHL-box and SOCS-box domains determine binding specificity for Cul2-Rbx1 and Cul5-Rbx2 modules of ubiquitin ligases. Genes Dev. 18: 3055-3065.

Kile BT, Viney EM, Willson TA, Brodnicki TC, et al. (2000). Cloning and characterization of the genes encoding the ankyrin repeat and SOCS box-containing proteins Asb-1, Asb-2, Asb-3 and Asb-4. Gene 258: 31-41.

Kile BT, Metcalf D, Mifsud S, Di Rago L, et al. (2001). Functional analysis of Asb-1 using genetic modification in mice. Mol. Cell Biol. 21: 6189-6197.

Kohroki J, Fujita S, Itoh N, Yamada Y, et al. (2001). ATRA-regulated Asb-2 gene induced in differentiation of HL-60 leukemia cells. FEBS Lett. 505: 223-228.

Kwok P-Y (2003). Single nucleotide polymorphisms: methods and protocols. Humana Press, Totowa, USA.

Legarra A, Calenge F, Mariani P, Velge P, et al. (2011). Use of a reduced set of single nucleotide polymorphisms for genetic evaluation of resistance to Salmonella carrier state in laying hens. Poultr. Sci. 90: 731-736.

Liu W, Yu Y, Li G, Tang S, et al. (2012). Single-nucleotide polymorphisms in the promoter of the growth hormonereleasing hormone receptor gene are associated with growth and reproduction traits in chickens. Anim. Genet. 43: 564-569.

Lu Y, Chen SR, Liu WB, Hou ZC, et al. (2012). Polymorphisms in Wnt signaling pathway genes are significantly associated with chicken carcass traits. Poultr. Sci. 91: 1299-1307.

McDaneld TG and Spurlock DM (2008). Ankyrin repeat and suppressor of cytokine signaling (SOCS) box-containing protein (ASB) 15 alters differentiation of mouse $\mathrm{C} 2 \mathrm{C} 12$ myoblasts and phosphorylation of mitogen-activated protein kinase and Akt. J. Anim. Sci. 86: 2897-2902.

McDaneld TG, Hancock DL and Moody DE (2004). Altered mRNA abundance of ASB15 and four other genes in skeletal muscle following administration of beta-adrenergic receptor agonists. Physiol. Genomics 16: 275-283.

McDaneld TG, Hannon K and Moody DE (2006). Ankyrin repeat and SOCS box protein 15 regulates protein synthesis in skeletal muscle. Am. J. Physiol. Regul. Integr. Comp. Physiol. 290: R1672-1682.

Meydan H, Yildiz MA, Dodgson JB and Cheng HH (2011). Allele-specific expression analysis reveals CD79B has a cisacting regulatory element that responds to Marek's disease virus infection in chickens. Poultry Sci. 90: 1206-1211.

Moonen RM and Villamor E (2011). Developmental changes in mesenteric artery reactivity in embryonic and newly hatched chicks. J. Comp. Physiol. B 181: 1063-1073.

Nei M and Roychoudhury AK (1974). Sampling Variances of heterozygosity and genetic distance. Genetics 76: 379-390.

Nie QH, Fang MX, Xie L, Shen X, et al. (2010). Associations of ATGL gene polymorphisms with chicken growth and fat traits. J. Appl. Genet. 51: 185-191.

Rao YS and Zhang XQ (2007). Single nucleotide polymorphisms and fine mapping QTL in chickens. Yi Chuan 29: 393 398.

Spurlock DM, McDaneld TG and McIntyre LM (2006). Changes in skeletal muscle gene expression following clenbuterol administration. BMC Genomics 7: 320.

Sun G, Li M, Li H, Tian Y, et al. (2013). Molecular cloning and SNP association analysis of chicken PMCH gene. Mol. Biol. Rep. 40: 5049-5055.

Tang S, Sun D, Ou J, Zhang Y, et al. (2010). Evaluation of the IGFs (IGF1 and IGF2) genes as candidates for growth, body measurement, carcass, and reproduction traits in Beijing You and Silkie chickens. Anim. Biotechnol. 21: 104-113.

Uemoto Y, Sato S, Ohtake T, Sato S, et al. (2011). Ornithine decarboxylase gene is a positional candidate gene affecting growth and carcass traits in F(2) intercross chickens. Poultr. Sci. 90: 35-41.

Wang QG, Guan TZ, Wang SZ, Zhang H, et al. (2011). Association between chicken A-FABP gene polymorphisms and growth and body composition traits. Yi Chuan 33: 153-162.

Wilcox A, Katsanakis KD, Bheda F and Pillay TS (2004). Asb6, an adipocyte-specific ankyrin and SOCS box protein, interacts with APS to enable recruitment of elongins B and C to the insulin receptor signaling complex. J. Biol. Chem. 279: 38881-38888.

Xie L, Luo C, Zhang C, Zhang R, et al. (2012). Genome-wide association study identified a narrow chromosome 1 region associated with chicken growth traits. PLoS One 7: e30910.

Yeh JJ, Marsh DJ, Zedenius J, Dwight T, et al. (1999). Fine-structure deletion mapping of 10Q22-24 identifies regions of loss of heterozygosity and suggests that sporadic follicular thyroid adenomas and follicular thyroid carcinomas develop along distinct neoplastic pathways. Gene. Chromosome. Cancer 26: 322-328. 